\title{
A DEMONSTRATION OF THE ORIGIN OF TWO PAIRS OF FEMALE IDENTICAL TWINS FROM TWO OVA OF HIGH STORAGE ${ }^{1}$ METABOLISM
}

\author{
OSCAR RIDDLE \\ From the Station for Experimental Evolution, Cold Spring Harbor, L. I., N. Y. \\ THIRTEEN TABLES
}

Much has been written on identical twins; but, assuming that it is a fact that such twins arise from the first two blastomeres of a single ovum, not a single fact seems to be known concerning either of the first two questions which one is tempted to ask concerning the germs from which such twins arise. Probably the first of these questions is, If identical twins arise from two separated blastomeres, why do the blastomeres separate in these special and particular cases? Second, What functional differences characterize two such ova that produce male twins in one instance and female twins in the other? It is possible that the data presented here do not supply us with a fact concerning the reason for the separation of the two blastomeres in these occasional instances. A suggestion on this point is offered. But the present data do, beyond question, give us a fact concerning the functional status of two particular germs which produced two pairs of female identical twin ring-doves.

In my earlier studies ${ }^{2}$ on the eggs (yolks) of doves and pigeons it was learned that males arise from eggs (yolks) of lesser storage metabolism (small size, and higher metabolism), and females from eggs (yolks) of greater storage metabolism (large size, and

${ }^{1}$ High storage metabolism is to be interpreted as low (oxidizing) metabolism.

${ }^{2}$ See, a) Science, N. S., vol. 35, pp. 462-463, March 22, 1912; b) Carnegie Year Book, no. 12, p. 322, 1913; c) Bulletin of the American Aeademy of Medicine, vol. 15, no. 5, pp. 265-285, October, 1914; d) American Naturalist, vol. 50, pp. 385-410, July, 1916; e) Journal of the Washington Academy of Sciences, vol. 7, no. 11, June 4, 1917; f) Science, N. S., vol. 46, pp. 19-24, July 6, 1917. 
lower metabolism). I have now obtained two cases of female identical twins, and am able to know that the ova (yolks) which produced both of them were extraordinarily and abnormally large.

We may first note that these two instances supply a strong confirmation of my earlier conclusion concerning the correlation of high-storage yolk válues and femaleness. Next we may examine the data which demonstrate that the twin-producing yolks were of exceptionally large size.

\section{SIZE OF EGGS AND YOLKS IN RELATION TO THE TWO CASES OF TWINS}

The yolk of a dove's egg cannot, of course, be directly weighed on a balance and then be incubated with the hope of producing young. But, as we shall see, the two procedures on the same egg are unnecessary to the demonstraiton that the twin-producing yolks were of extraordinary size. Again, the weights of two entire eggs (yolk + albumin + shell) from the same bird, and the same clutch, may be different and yet this difference not indicate which egg contains the larger yolk (ovum). But the amount which two such eggs may thus differ, without showing the direction of difference in the yolks, is limited. And, for the species under consideration, as well as for several others, the limits of such difference are now approximately known. Accurate direct weighings of nearly 15,000 yolks of various pigeon species and hybrids have been made. Probably nearly 4,000 of these are eggs of the species which produced these two instances of twins. Certain aspects of these data will be utilized here for the purpose just indicated.

One of the twin-producing eggs was the seventy-sixth egg laid by that particular female. The other twin arose from the fiftieth egg of another female. In our main study the complete egg-laying history is kept of some hundreds of doves and pigeons. We are here able, therefore, to give the exact weight of every egg produced by each of these two twin-producing females prior to, as well as after, the appearance of their twin-producing eggs. For the blond ring female (No. A248) this record is given com- 
plete in table 1. The similar record of the hybrid ${ }^{3}$ female (No. 60 ) is given in table 2. A glance at those two tables will show how conspicuously larger is each of the twin-producing eggs than is any other egg of the series to which it belongs; the tables give the necessary details for one hundred ${ }^{4}$ eggs of one series and ninety-seven in the other.

The extraordinarily large size of the eggs which produced the twins, in comparison with all of the other eggs produced by these particular parents (totals of 116 and $134 \mathrm{eggs}$ ), is itself sufficient to make it extremely probable that the yolks contained within them were of very large size. The certainty of their large yolk size becomes apparent in the light of the results of our accurate measurements on many thousands of eggs. It is, of course, impossible to give all of these latter measurements here; this is also unnecessary since these will appear in connection with the complete account of our studies on sex in pigeons. It does seem necessary, however, to give here the particular segment of this evidence which is contained in the several following tables.

Reference to tables 5 and 6 will show that the eggs which produced the twins were, in one case, 24.9 per cent, and in the other, 43.1 per cent larger than the associated egg (of the same clutch). Such amounts of difference between the two eggs of the clutch are highly abnormal; except in cases of evident dwarfing of the smaller egg of the pair they practically do not exist. In the two pairs of twin-producing eggs it will be observed that the smaller eggs of the pairs are not dwarfed. A number of cases approximating to these extreme differences have, however, appeared in our records. An assistant has gone through the entire body of our breeding records and listed all pairs of eggs in which the members of the pair differ by 20 per cent or more (tables 7 to 12 ). In connection with these summaries it was thought advantageous

\footnotetext{
3 This female is hybrid between two very closely related ring-doves-Streptopelia alba and St. risoria $\left(\frac{7}{8}\right.$ alba, $\frac{1}{8}$ risoria).

${ }^{4}$ Sixteen additional eggs (to December 1) have since been laid by female A248; the largest egg weight among these is 9.40 grams. Thirty-seven eggs have since been added to the series containing ninety-seven eggs, and the largest egg weight among these is 9.11 grams. Most of the tables of this paper are summaries of data collected to April, 1917.
} 
to list all pairs of eggs (of whatever per cent of difference in weight) in which the yolks weights had been obtained and were found to differ by as much as 35 per cent. This latter amount is likewise abnormal for yolk weight differences; usually, this difference (in pure species) is only about 9 to 15 per cent. Since the egg weights of incubated eggs are thus included, the lists as given contain all of the strikingly abnormal or ill-matched pairs of eggs that have been encountered among the nearly 20,000 doves' eggs that we have studied. These selected data are partially classified in the tables ( 7 to 12) according to the kind of female which produced the eggs.

Several of these pairs of disproportionately sized eggs have been incubated and the sex of the resulting offspring learned; these data are also fully given in the tables. Sex is certainly correlated with the size, or storage metabolism, of the ova (yolks); and, in pure species, both of these are certainly correlated with the order of the egg in the clutch, as has also been pointed out in earlier publications already cited. In hybrids, however, and most markedly in the hybrids from the wider (generic) crosses, any regularity of the presence of smaller yolks in the first eggs of the clutch is lost. At the same time a high predominance of males from the first and of females from the second eggs of the clutch is also lost. Some instances of these conditions will be observed in the tables. But, as we have previously pointed out, there are conditions other than yolk size which also influence the sex that is to proceed from a particular yolk. A sperm from a different genus, or subfamily, may cause a male to arise from an ovum which, if fertilized by its own species, would have produced a female.

Further, there is at hand considerable evidence in favor of the following interpretation: The sperms formed by hybrids, particularly by generic, subfamily, and family hybrids, are of the most varying degrees of fertilizing power. That is to say, the sperms produced by a particular male vary thus, and these sperm. differences are probably not devoid of power to influence both the degree of development and the sex of the offspring from the ovum with which the sperm unites. In still other words, differ- 
ent sperm from the same hybrid male may exercise opposite tendencies for the production of sex. ${ }^{5}$ A probable instance $(Q$ of 265) of this is partially described in the footnote to table 8 .

The females which produced the twins, and the eggs listed in tables 1 and 2, were mated to blond ring-dove (Streptopelia risoria) males. Indeed, these males are sire and son; and, further in one of the series the sire is mated to his daughter (A248). The hybrid female (alba-risoria No. 60) is thus mated with one of her parent species, and the two species which enter into her composition are closely related ones. In consequence both of these female tend-aside from special modifying conditionsto throw higher proportions of males from first eggs of the clutch and of females from the second eggs of the clutch (tables 3 and 4 ). The bisexual clutches (those producing the two sexes) are considered in tables 5 and 6 . Among these latter this proportion is $5: 1$, or $5: 3$ (?) for female A248, ${ }^{6}$ and $12: 7$ for female 60 .

Reference to table 7 will show that all pairs of eggs obtained from pure blond rings which differed by as much as 20 per cent in weight had yolk weights which differed in the same sense as the egg weights; i.e., in this pure species, the yolk of the second egg was invariably (seven cases) larger than the yolk of its clutch mate, when the total weight of the second egg was 20 or more per cent larger than the egg weight of the clutch mate. In the case of the twin-producing egg belonging to this series the eggweight difference was 43.1 per cent; this very wide difference fully guarantees the larger size of the yolk which it contained and which gave rise to the twins.

The difference ( 43.1 per cent) is also far greater than that of any of the thirty-five pairs of yolks weight of alba-risoria hybrids given in table 8 . That table shows that every egg-weight difference of more than 14 per cent correctly indicated the direction of the difference between the pairs of yolks produced by these

\footnotetext{
${ }^{5}$ The factual support of this unorthodoxy must, after consulting the papers eited under note 2 , in part await the publication of, a) C. O. Whitman, Posthumous Works, vol. II (The Carnegie Institution, in press) and, b) our own forthcoming work.

6 Some evidence from inbred relatives of this bird possibly indicate a slight contamination of $S t$. alba in this female.
} 
hybrids. In only one case of the thirty-six clutches listedone in which the difference in egg weight was only 13.9 per centdid the difference in egg weight fail to show which egg contained the larger yolk. This failure, moreover, concerns the first pair of eggs laid during the life of the bird, and this has long since been observed to be a clutch in which the usual order, both of sex delivery and of yolk size, is more often disturbed or reversed. It may be incidentally noted that the first clutch produced after prolonged reproductive rest is similarly disposed-even in pure species - to supply a large yolk to the first egg and a small one to the second egg, and to reverse the normal order of the resulting sexes in the same sense.

Table 8 will show that the other twin-producing egg, that of hybrid female No. 60, was an extraordinarily large egg when compared with the extraordinarily large eggs produced by any and all of our hybrids of similar or related kinds. Only three eggs of the fifty-two pairs from all similar sources equaled it in size. The data of the table leave no doubt that this twinproducing egg contained a yolk of unusually large size.

The effects of hybridity in the female on the regularity of delivery of larger eggs and yolks in second eggs of the clutch (as indicated by the segment of data contained in the several tables) may be summarized as follows:

Pure St. risoria............. $\left\{\begin{array}{l}\text { Eggs 2nd larger, 20; smaller, } 0 \\ \text { Yolks, 2nd larger, 7; smaller, } 0\end{array}\right\}($ table 7$)$

Pure St. alba and T. orientalis.. $\left\{\begin{array}{l}\text { Eggs, 2nd larger, 6; smaller, } 0 \\ \text { Yolks, 2nd larger, 2; smaller, } 0\end{array}\right\}$ (table 9)

Risoria-alba hybrids.......... $\left\{\begin{array}{l}\text { Eggs, 2nd larger, 48; smaller, } 4 \\ \text { Yolks, 2nd larger, 48; smaller, } 4\end{array}\right\}$ (table 8)

Miscellaneous hybrids......... $\left\{\begin{array}{l}\text { Eggs, 2nd larger, 14; smaller, 4 } \\ \text { Yolks, 2nd larger, 11; smaller, 5 }\end{array}\right\}$ (table 10)

Common pigeons............ $\left.\begin{array}{l}\text { Eggs, 2nd larger, 2; smaller, 2 } \\ \text { Yolks, 2nd larger, 1; smaller, } 3\end{array}\right\}$ (table 12)

Alba-orientalis hybrids (generic
hybrids).................. $\left\{\begin{array}{l}\text { Eggs, 2nd larger, 27; smaller, 35 } \\ \text { Yolks, 2nd larger, 26; smaller, 34 }\end{array}\right\}$ (table 11) 
It is clear, therefore, that these data justify the preceding statement on the effects of hybridity upon the normal size relations of the two yolks (ova) of the pigeon's clutch. They also emphasize the fact that the two twin-bearing eggs were from bird groups which assuredly throw a very high proportion of larger yolks in the second egg of the clutch. Both twin-producing yolks were, as already noted, the second of the clutch.

The two series of breeding records which supplied these two cases of twins (tables 1 and 2) afford an opportunity partially to illustrate still another condition which affects the sex production, and to a certain extent the storage capacities, of the ova of pigeons. In earlier papers we have referred to 'crowded reproduction' merely as an aspect of 'reproductive overwork.' We can here particularize to the extent indicated in tables 1 to 4 .

The summaries at the bottom of tables 1 and 2 , and the four divisions (columns 2 and 3 ) of tables 3 and 4 , show that the sex ratio changes with the rate at which the eggs are produced. In the case of 9 A248 (table 1) those clutches which were separated from the preceding clutch by an interval of eight days or more yielded $26 \sigma^{7}: 13$ o (sex unknown 9); those of seven-day intervals, $90^{\pi}: 23 \%$ (unknown 8); and those of six-day intervals, $4 \sigma^{7}: 8$ (unknown 0 ). For the hybrid $\% 60$ (table 2 ), the corresponding figures are: $26 \sigma^{7}: 27 \%$ (unknown 8); $5 \sigma^{7}: 11$ \% (unknown 2);2 $\sigma^{7}: 9$ ( 9 (unknown 5). Under the most crowded reproduction (six and seven days) in these two series it is clear that there is an undoubted deficiency of males, even if all of the eggs of unknown sex value were classed as males. The fact that one pair of twins arose from a clutch with a six-day interval (table 1) and the other from a seven-day interval (table 2)-is therefore significant for the purposes of the present paper. The actual time intervals involved predisposed, so to speak, these clutches to femininity, and both our published and unpublished data show conclusively that femininity is correlated with a high storage metabolism of the ova.

Tables 3 and 4 supply still a different method of analysis of the relation of 'crowded reproduction' to sex. In column 2 of those tables the whole period of egg laying (shown in tables 1 and 2) 
is divided into its natural divisions; i.e., into the actual periods of work and rest of the female parent. It will be observed that both females threw highest proportions of male offspring from the longest clutch intervals and fewest from the shortest intervals. In the eight instances there is not an exception. Moreover, when each of these natural periods is subdivided into a first and last half and the clutch intervals and the sex ratios are calculated anew (columns 2 and 4, tables 3 and 4), the same fact is again demonstrated. When the undivided natural periods are put alongside the sex ratios, calculated as percentages, the figures speak for themselves:

\section{Q A 248}

$16.5 \mathrm{da}=20^{\pi}: 1 \%=33.3 \%$ females

$7.6 \mathrm{da} .=160^{7}: 10 \%=38.5 \%$ females

$7.4 \mathrm{da}=17 \sigma^{7}: 17$ q $=50.0 \%$ females

$7.0 \mathrm{da}=40^{7}: 16 \%=80.0 \%$ females

Twin from six-day interval

$$
\begin{gathered}
\wp 60 \\
14.5 \mathrm{da} .=12 \sigma^{7}: 10 \%=45.5 \% \text { females } \\
9.9 \mathrm{da} .=10 \sigma^{7}: 10 \%=50.0 \% \text { females } \\
7.7 \mathrm{da} .=6 \sigma^{7}: 15 \%=71.4 \% \text { females } \\
7.1 \mathrm{da} .=4 \sigma^{7}: 11 \%=73.3 \% \text { females } \\
\text { Twin from seven-day interval }
\end{gathered}
$$

In this connection we may consider the question whether the parents continued to produce eggs immediately after the twinproducing eggs were laid and what was demonstrated as to the sex ratios in these eggs. Reference to table 2 will show that the hybrid female (60) laid only one other clutch of eggs before taking a rest (forty-four days). We are therefore unable to say what the sex ratio from this female would have been had she continued 'crowded reproduction.' The period of rest is, of itself, however, an evidence of the weakness (following overwork) which we have learned to associate with a high proportion of females. But even the next complete reproductive period following this period of rest yielded eleven females to four males, with two additional embryos too weak to hatch. In the case of the other twinproducing parent ( 9 A248, table 1) it will be observed that egg laying was continued at regular seven-day intervals for twelve clutches after the twin-bearing clutch. From these eggs four males and sixteen females were produced, and four eggs were too weak in developmental power to permit us to know their prospective sex. Here one series of eight consecutive eggs produced females; another unbroken series of five eggs produced females. 
Unquestionably, in the parents which supplied a test of the matter, the twin-bearing egg was immediately succeeded by the production of a high proportion of female-producing eggs.

The question of variations in the relation of yolk weight to egg weight under the conditions of reproductive overwork and of 'crowded reproduction' is not answered by the data of the tables given here and lies outside the scope of this paper. For the present purpose, and by way of summary, it may be observed that both cases of twin-producing eggs occurred, a) in reproductively overworked females; b) in periods of 'continuous activity;' c) in very short intervals - six and seven days-since the preceding clutch, and, finally, that such crowded reproduction tends to produce an excess of females.

\section{DOUBLE-YOLKED EGGS IN DOVES AND PIGEONS}

There remains for consideration the possibility of the origin of the two cases of twins from 'double-yolked' eggs. Two sets of facts show that this did not occur. We may first note the conclusive data obtained from the twins themselves, and from the eggs that produced them, and later produce the record of the few cases of double-yolked eggs that have appeared in our studies with doves and pigeons.

The pertinent facts concerning the first pair of twins (from o60) are as follows: This egg was laid on March 7, and failing to hatch on March 22, was opened for examination. Two nearly full-term dead embryos were found; both birds were plainly smaller than normal birds ready to hatch, but both seemed practically completely formed and ready to hatch. A very considerable amount of yolk, however, remained unabsorbed, and both umbilici were plainly united at a nearly common point on the single yolk-sac. Both young were plainly females; in one of the two there was a distinct right ovary as well as the usual left ovary, but I was unable to make sure that a similar right ovary was also present in the other.

The facts obtained on the second twin-bearing egg (from o A248) were as follows: When this egg was candled (held toward the light, as is done on the second to the fifth day for all eggs 
incubated) to test its fertility on the third day of incubation, two embryos were plainly seen. It was then noted that the two were close together; that in moving, turning, or shaking the egg, they invariably turned together, and that their position with reference to each other could not be altered. Clearly they were contained within the same ovum. It was thus known in advance that this was a twin-bearing single yolk. On the fourteenth day of incubation--just before the young were due to hatch-the egg was opened so as better to learn the conditions presented by the twins. Two young were found, one dead, the other alive. The dead young was practically a full-term embryo, perhaps slightly larger than the live one which seemed nearly ready to hatch. There remained here also a considerable amount of unabsorbed yolk; and, as in the previous case, the umbilici had a practically common point of union on the yolk-sac. Both birds were plainly females ${ }^{7}$ and both birds possessed right ovaries which were one-half as large as the left ovaries.

Five 'doubled-yolked' eggs have appeared among the approximately 20,000 doves' eggs that have been examined. The size of these eggs compared with the other egg of the clutch, and with the size of the eggs of the immediately preceding and succeeding clutches, is given in table 13. Four of the five cases occurred among the eggs of hybrids. The one case of a female of pure species (Stigmatopelia senegalensis) was supplied by a female which otherwise showed the following reproductive abnormalities: Two clutches immediately preceding the doubleyolked egg were clutches of one egg each; previous to these she had laid fifteen clutches, fourteen of which consisted of two eggs. The double-yolked egg was the last egg produced during the year (November 25), and the last in life for this bird, except that an egg was present in her oviduct when she died three and one-half months (March 5) later.

The second of the double-yolks was produced by a female hybrid (alba $\times$ risoria) from her third egg in life. The two yolks of this egg were of most strikingly abnormal size - both together being

${ }_{7}$ The sex can usually be definitely learned in nine- to ten-day embryos of those species whose incubation period is from fourteen to fifteen days. 
little more than one-half the size of one normal yolk for birds of this kind. The immediately preceding eggs and the succeeding one were similarly much undersized. And, further, this female produced eggs at an abnormally slow rate during the entire year.

The third double-yolked egg was produced by a generic hybrid (T. orientalis $\times$ St. alba), whose reproductive record seems to be fairly normal for her kind. She was mated to another female when the double-yolked egg was produced.

The fourth and fifth of these double-yolked eggs were also produced by generic hybrids. The fourth was from a Stig. senegalensis $\times$ St. alba hybrid. It was produced only five days after a preceding clutch-a thing of most unusual occurrence; in another case she produced two clutches, of one egg each, only four days apart. ${ }^{8}$ The fifth egg was from a complex generic hybrid (of three species, orientalis, risoria, alba), which produced eggs during only one season, and only three clutches after the abnormal one containing the double-yolk.

From the above records it seems clear, therefore, that doubleyolked eggs of doves are practically restricted in their production to hybrids from wider crosses or to birds showing striking reproductive abnormalities or to both of these. The history of the few cases of double-yolks that are known would indicate, then, that such eggs would not be expected to appear in the series in which the two cases of twins were found.

\section{ON THE CAUSE OF THE FORMATION OF IDENTICAL TWINS}

At the beginning of this paper it was stated that on the basis of the present data a suggestion could be offered as to the reason for the occasional separation of the blastomeres which leads to the production of identical twins. Possibly the data do not really provide such a suggestion; but, knowing that the two eggs that produced two pairs of identical twin ring-doves were from yolks

\footnotetext{
8 These eggs may of course be considered as of the same clutch; in this case the abnormality would consist in the time interval being a four-day period instead of the normal forty hours.
} 
of most extraordinary size, the writer can not but wonder if there existed a causal nexus between the extraordinary size, on one hand, and the unusual separation of the blastomeres on the other.

Plainly the main question is, Why, or by what means, is 'independen ' development instead of coördinated, mutual, integrated development initiated in the two blastomeres? One means already known for obtaining this 'independent development' is that of physical separation of the blastomeres. Surely, the exact placement and position and inclination of the early blastomeres (meroblastic eggs) are not wholly out of reference to the size and to the consequent polar configuration. And surely the type of cleavage, normal to normal blastula-formation, etc., is not out of reference to the normal size and shape of the ovum. A somewhat unusual disposition of the segmentation spheres at the animal pole--these being, at their outer borders, abnormally raised in extraordinarily large eggs and abnormally lowered in extraordinarily small ones-would thus seem to afford a possible clue to this relatively rare occurrence.

In holoblastic eggs the egg-size might still be the conditioning factor, as in the case just noted of meroblastic eggs; for, although the blastomeres there are always in apposition, the centers of metabolic activity (nuclei, centrosomes, etc.) in abnormally large eggs would be separated to a degree unusual to the species, and thus conceivably afford a basis for the 'independent action' of the first two segmentation spheres. Abnormally small ova, in division, would provide two cells with abnormally (for the species) large surface areas in proportion to their masses, and conceivably this may similarly result in the immediate assumption of 'independent development' in each blastomere.

According to the view just sketched, identical twins should arise from the extremely large and the extremely small eggs of a species. Presumably such would be produced in approximately equal numbers. According to the theory of sex hitherto developed by the writer, males should develop from the smallest and females from the largest eggs. Apparently, the same size relations should hold for the sexes in twin-producing eggs. The two cases of identical twins described in this paper are two instances in sup- 
port of both of the above-mentioned views. A few cases of identical male twins from extremely small ova of the pigeon would completely establish the view as stated for twinning in pigeons. Our present data undoubtedly establish the relations of yolk size to sex and give much warrant for the prediction that if identical male twins ever arise from the ova of doves and pigeons they will arise from small ova.

In conclusion, it may be emphasized that the correctness or incorrectness of the tentative hypothesis concerning the causes of twin-formation, as stated in the immediately preceding paragraphs, is unimportant to the main purpose of the present paper. The available data concerning the germs which gave rise to two pairs of female twins demonstrate that each pair arose from a single ovum and that each pair arose from an ovum of high storage metabolism. 


\begin{tabular}{|c|c|c|c|c|c|c|c|c|c|c|}
\hline & 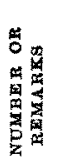 & 오욥 & 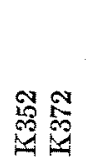 & 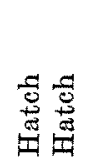 & 预 & 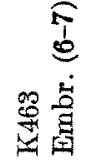 & 焉 & 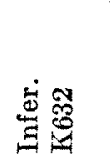 & 续 : & 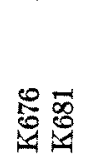 \\
\hline & 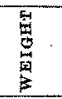 & $\begin{array}{l}\infty \\
\infty \\
N\end{array}$ & $\begin{array}{l}80.8 \\
80 \\
10 \\
\end{array}$ & $\begin{array}{l}\infty \\
\sim \\
\sim\end{array}$ & 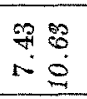 & $\begin{array}{l}\infty \\
\stackrel{\infty}{\infty} \\
\infty \infty \\
\infty\end{array}$ & $\begin{array}{l}\text { Nิ R } \\
\infty \infty \infty \\
\infty\end{array}$ & $\begin{array}{l}88 \\
58 \\
\end{array}$ & $\begin{array}{r}98 \\
\infty \\
\infty \\
\end{array}$ & $\begin{array}{ll}0 & 0 \\
\infty & 0\end{array}$ \\
\hline & $\stackrel{g}{4}$ & 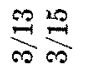 & 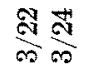 & 总 & $\stackrel{5}{\circ}$ & 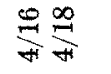 & 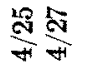 & $\frac{1}{10}$ & $\stackrel{20}{10}_{10}^{20}$ & 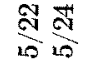 \\
\hline & 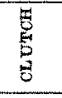 & $\boldsymbol{\Xi} \boldsymbol{\Phi}$ & $\vec{\approx} \cong$ & $F$ & $\bar{A}$ & $\vec{\exists}$ & 帘愛 & 台学 & $\overrightarrow{0} \mathscr{O}$ & $\bar{\Xi}$ \\
\hline 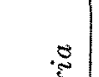 & $\begin{array}{l}x \\
\text { 涪 } \\
2\end{array}$ & ot 5 & $5 \%$ & $0+5$ & $\begin{array}{r}50 \text { ot } \\
\text { of } \\
\end{array}$ & $\delta_{0}$ & ro ot & $\alpha$ & ot ot & ot ot \\
\hline 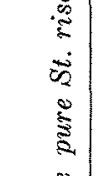 & 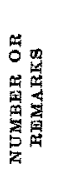 & 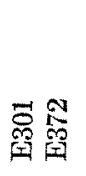 & 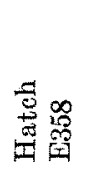 & 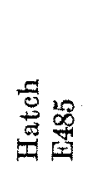 & 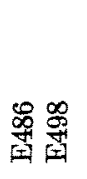 & 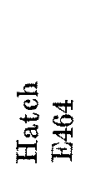 & 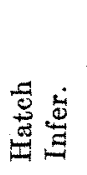 & 䒴葶 & 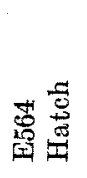 & 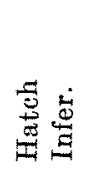 \\
\hline 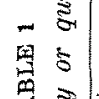 & 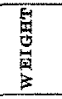 & $\begin{array}{l}19 \\
19 \\
0: 1 \\
\end{array}$ & $\begin{array}{l}\stackrel{\infty}{\infty} \stackrel{0}{\circ} \\
1-\infty\end{array}$ & $\begin{array}{l}\infty \\
+2 \\
i \infty \\
-\infty\end{array}$ & 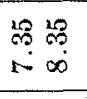 & 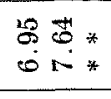 & $\begin{array}{l}\text { Nิ } \\
\stackrel{m}{\infty} \\
i\end{array}$ & 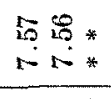 & 识? & $\begin{array}{l}8 \infty \\
N \infty\end{array}$ \\
\hline 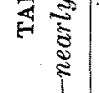 & 管 & $\underset{\infty}{\infty} \underset{\infty}{\infty}$ & 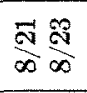 & $5 \frac{10}{0}$ & $\underset{\sigma}{ت} \stackrel{\infty}{\sigma}$ & $\begin{array}{l}\overrightarrow{9} \mathfrak{N}^{*} \\
\sigma^{*} \\
\end{array}$ & 동옹 & 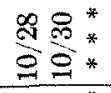 & $\vec{\Theta}$ & 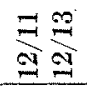 \\
\hline $\begin{array}{l}\infty \\
0 \\
0\end{array}$ & 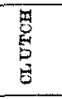 & $\overrightarrow{\mathrm{F}} \overrightarrow{\mathrm{A}}$ & 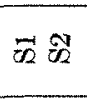 & $E \mathcal{F}$ & Б今 & $\overrightarrow{D P^{*}}{ }^{*}$ & $\vec{N}$ & $\vec{x} \mathscr{x}_{*}^{*}$ & $D N$ & $\mathrm{~N} \mathbb{N}$ \\
\hline $\begin{array}{l}3 \\
8\end{array}$ & 炎 & of ot & or & $5_{0} \sigma_{0}$ & $r_{0} r_{0}$ & 50 & $0+$ & 50 & $0+5$ & $\alpha$ \\
\hline نั & 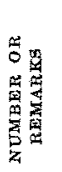 & 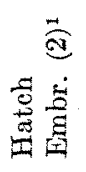 & 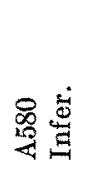 & 总离 & 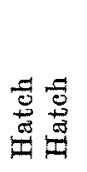 & 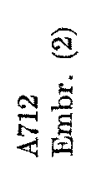 & 突学 & $\frac{8}{4}$ & 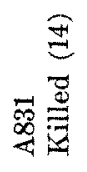 & $\begin{array}{l}\infty \\
\infty \\
\infty \\
4\end{array}$ \\
\hline & 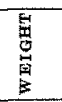 & 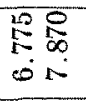 & 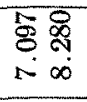 & 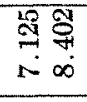 & 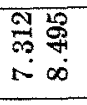 & 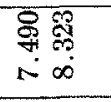 & $\begin{array}{l}\text { 吊 శ్ } \\
\sim \infty\end{array}$ & 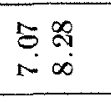 & $\begin{array}{l}8.28 \\
0 \infty \\
0 \\
\end{array}$ & 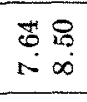 \\
\hline & 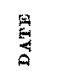 & 송 & 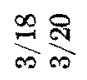 & 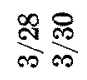 & $\stackrel{\infty}{\underset{\forall}{+}} \underset{+1}{\infty}$ & $\overbrace{\pi}^{\infty} \underset{-\infty}{\infty}$ & 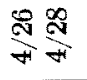 & 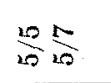 & $\stackrel{10}{20}_{20}^{10}$ & $\underset{20}{\stackrel{N}{N}}$ \\
\hline & 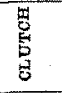 & दे दै & $\vec{\oplus} \tilde{\oplus}$ & రే & $\vec{A} \tilde{A}$ & 田第 & 成感 & $\overrightarrow{0}$ & 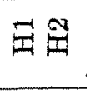 & $\exists \cong$ \\
\hline & 篦 & $\stackrel{0}{a+}$ & $r_{0}$ & $\delta_{0} \sigma_{0}$ & 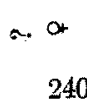 & or & $5_{0} \sigma_{0}$ & $\sigma_{0}$ ot & ot ot & or \\
\hline
\end{tabular}




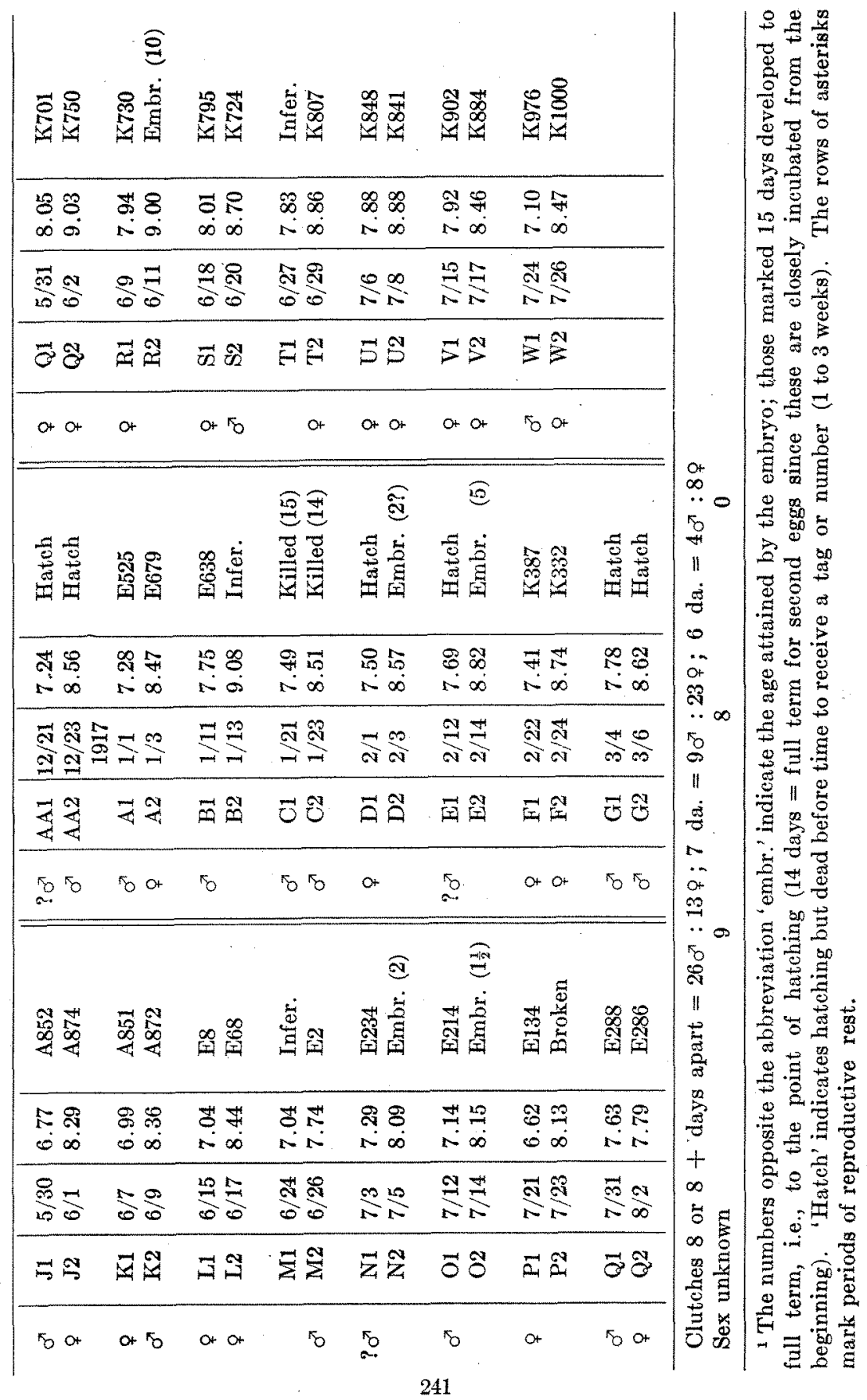




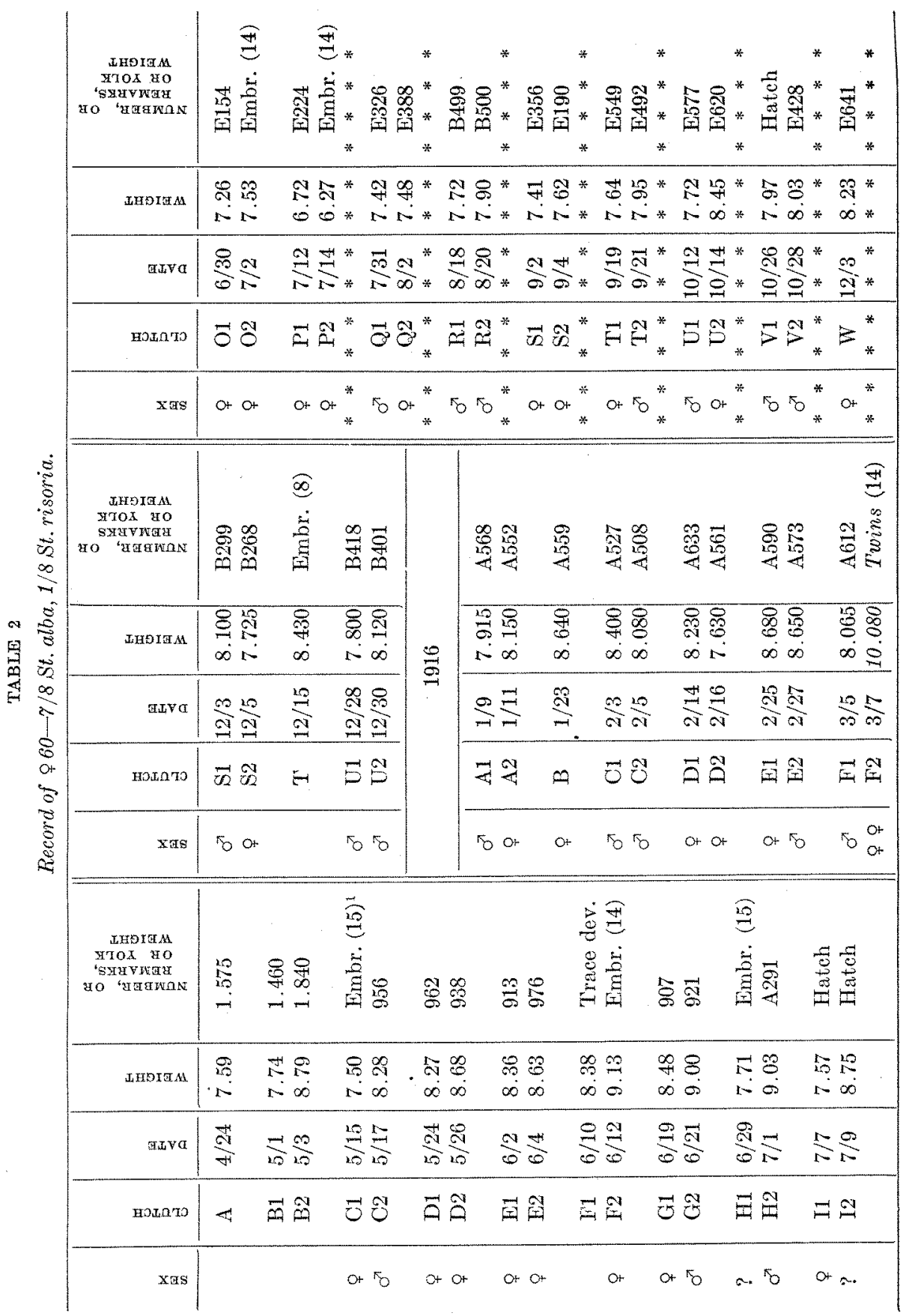




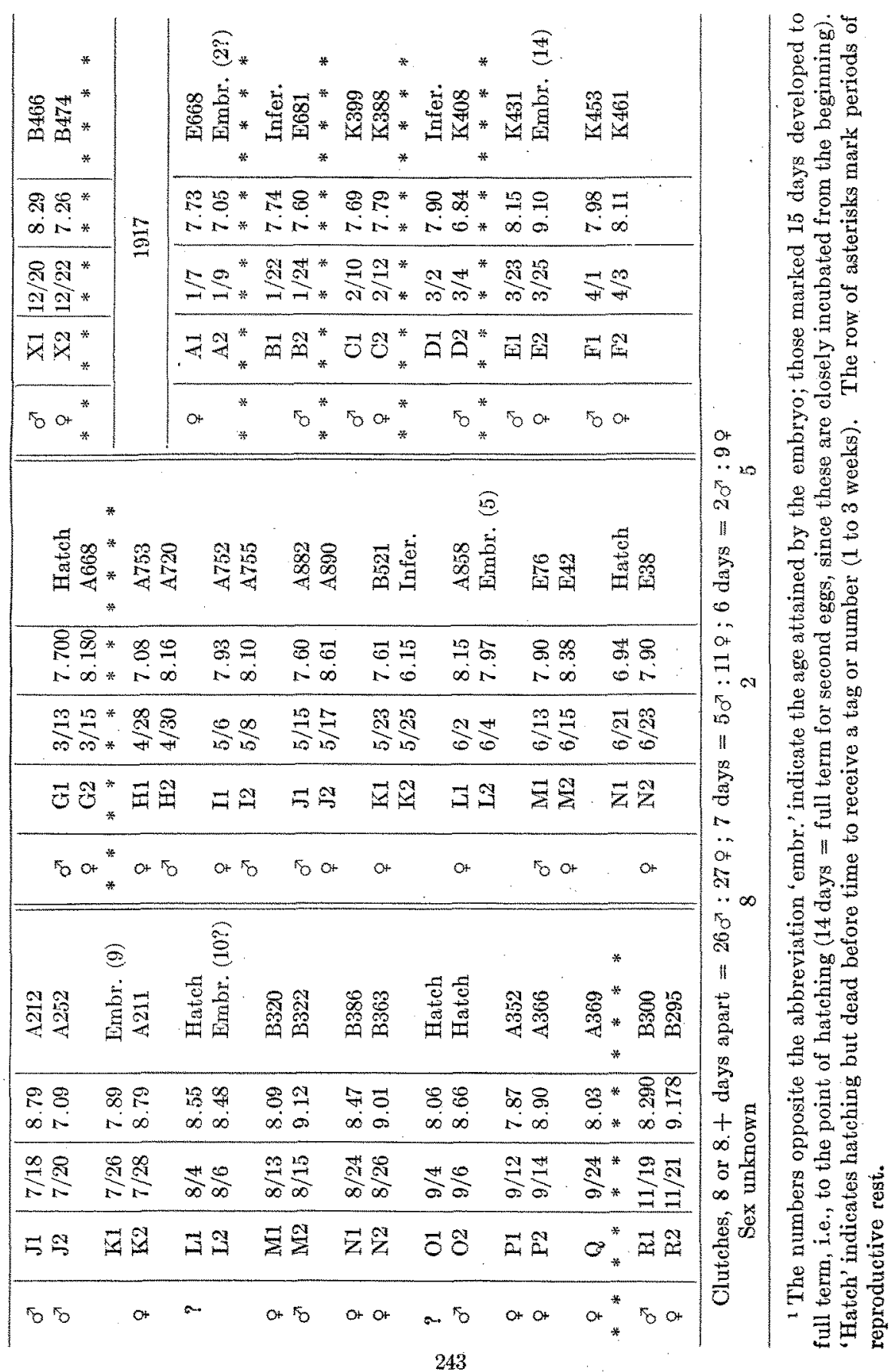

THE JOURNAL OF EXPE RIMENTAL ZOOZOQY, พOL, 26, No. 2 . 
TABLE 3

Further analysis of the data of table 2 , 9 No. A\$48 (nearly or quite pure St. risoria)

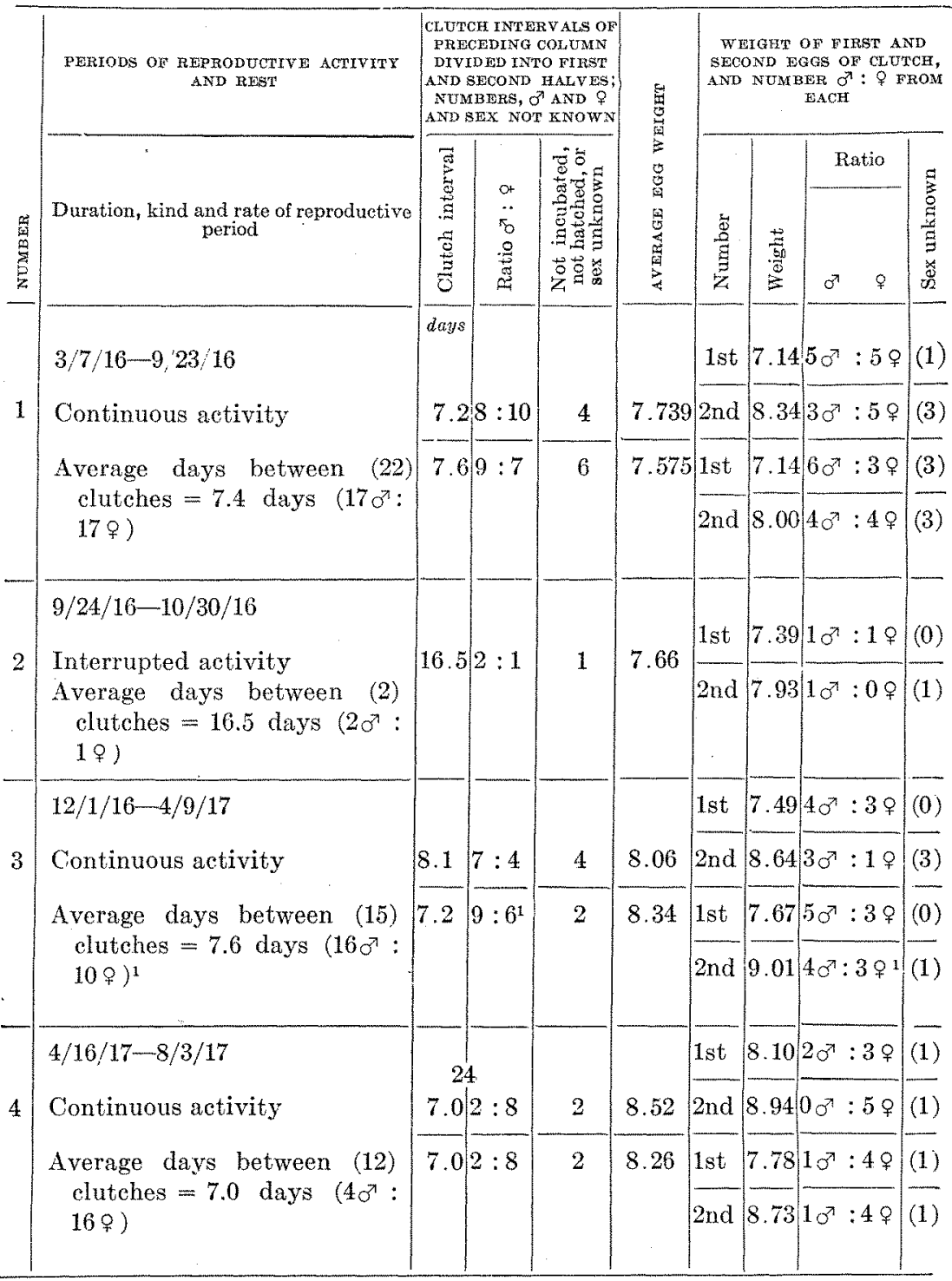

Total from 1st of clutch $=24 \sigma^{7}: 22 \%$ (unknown, 4); 2nd $=16 \sigma^{7}: 21 \%^{2}$ (unknown 13).

1 The last egg of this period produced female twins.

There is an additional female twin. Reference to table 1 will show that there were 13 second eggs of the clutch, predominantly female-producing eggs, which were (in 12 cases) too weak in development to permit a test of sex. The sex of only 4 first eggs of the clutch is unknown; only 2 of the 4 were too weak to hateh. This undoubtedly makes both the apparent number (21) and the proportion of females from the second eggs of the clutch much too small. 
TABLE 4

Further analysis of the data of table 1, 9 No.60 (hybrid $/ / 8$ St. alba, 1/8 St. risoria)

\begin{tabular}{|c|c|c|c|c|c|c|c|c|c|}
\hline \multirow[b]{2}{*}{ 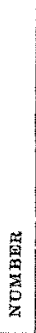 } & \multirow{2}{*}{$\begin{array}{c}\begin{array}{c}\text { PERTODS OF RIPRODUCTIV AC } \\
\text { TIVITY AND REST }\end{array} \\
\begin{array}{c}\text { Duration, kind and rate of repro } \\
\text { ductive period }\end{array}\end{array}$} & \multicolumn{3}{|c|}{\begin{tabular}{|} 
CLUTCH INTERVALS OF \\
PRECEDING COLUMN DI- \\
YLDED INTO FURST AND \\
SECOND HALVES; NUM- \\
BERS OH AND O , AND \\
OF SIXX NOT KNOWN
\end{tabular}} & \multirow{2}{*}{ 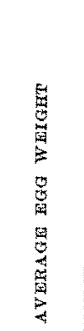 } & \multicolumn{4}{|c|}{$\begin{array}{l}\text { WEIGHT OF FIRST AND SEC- } \\
\text { OND EGGS OF CLUTCH, AND } \\
\text { NUMBER O } 0^{7}: 9 \text { FROM EACH }\end{array}$} \\
\hline & & 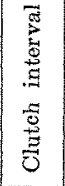 & 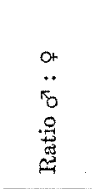 & 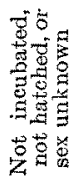 & & 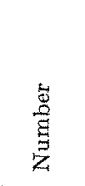 & 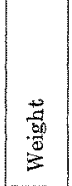 & Ratio & 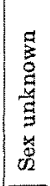 \\
\hline \multirow{4}{*}{1} & $4 / 24 / 15-9 / 24 / 15$ & $\begin{array}{c}\text { days } \\
7.7\end{array}$ & $3: 7$ & 5 & 8.372 & Ist & 8.06 & $00^{7}: 49$ & $(2)$ \\
\hline & Continuous activity & & & & & $2 n d$ & 8.79 & $30^{7}: 38$ & $(0)$ \\
\hline & Average days between (16) & 7.7 & $3: 8$ & 6 & 8.360 & let & 8.16 & $10^{\pi}: 4 \%$ & $(3)$ \\
\hline & $\begin{array}{l}\text { clutches }=7.7 \text { days }\left(60^{7}\right. \\
: 15 q)\end{array}$ & & & & & $\begin{array}{l}\text { 2nd } \\
\text { Sing. }\end{array}$ & $\begin{array}{l}8.60 \\
8.03\end{array}$ & $\begin{array}{r}2 \sigma^{7}: 3 q \\
-: 19\end{array} \mid$ & $\begin{array}{l}(3) \\
(0)\end{array}$ \\
\hline \multirow{4}{*}{2} & $11 / 19 / 15-3 / 15 / 16$ & & & & & 1 st & 8.03 & $4 c^{2}: 0 \%$ & $(0)$ \\
\hline & Continuous activity & 11.4 & $5: 4$ & 1 & 8.235 & $\begin{array}{l}\text { 2nd } \\
\text { Sing. }\end{array}$ & $\left|\begin{array}{l}8.44 \\
8.55\end{array}\right|$ & $\mid \begin{array}{l}10^{7}: 30 \\
-: 19\end{array}$ & $\begin{array}{l}(0) \\
(1)\end{array}$ \\
\hline & Average days between $(10)^{1}$ & & & & & 1st & 8.22 & $30: 28$ & $(0)$ \\
\hline & $\begin{array}{l}\text { clutehes }=9.9 \text { days } \\
\left(100^{7}: 10 q\right)^{3}\end{array}$ & 8.4 & $5: 6^{2}$ & 0 & 8.370 & 2nd & 8.52 & $30^{7}: 4 q^{2}$ & $(0)$ \\
\hline \multirow{4}{*}{3} & $4 / 28 / 16-7 / 14 / 16$ & 6.8 & $3: 4$ & 1 & 7.655 & 1 st & 7.55 & $10^{7}: 3 \%$ & $(0)$ \\
\hline & Continuous aetivity & & & & & 2 nd & 7.75 & $20^{7}: 10$ & $(1)$ \\
\hline & Average days between ( 8 ) & 7.4 & $1: 7$ & 2 & 7.502 & 1st & 7.39 & $10^{n}: 3 \%$ & $(1)$ \\
\hline & $\begin{array}{l}\text { clutches }=7.1 \text { days }\left(4 \sigma^{7}\right. \\
: 11 \%)\end{array}$ & & & & & 2nd & 7.61 & 00 & (1) \\
\hline \multirow[b]{2}{*}{4} & $7 / 15 / 16-3 / 25 / 17$ & & & & & 1st & 7.78 & $70^{\pi}: 3$ 우 & (2) \\
\hline & $\begin{array}{l}\text { Interrupted activity } \\
\text { Average days between (13) } \\
\text { elutches }=14.5 \text { days } \\
\left(120^{7}: 10 \%\right)\end{array}$ & 14.5 & $12: 10$ & 3 & 7.820 & $\begin{array}{l}\text { 2nd } \\
\text { Sing. }\end{array}$ & $\begin{array}{l}7.78 \\
8.23\end{array} \mid$ & $\left|\begin{array}{c}50^{7}: 7 \% \\
-: 1 \%\end{array}\right|$ & $\begin{array}{l}(1) \\
(0)\end{array}$ \\
\hline
\end{tabular}

Total from 1st of cluteh $=17 \sigma^{7}: 19 q$ (unknown 8); 2nd $=16 \sigma^{7}: 25 \%$ (unknown 6).

${ }^{1}$ Eleven clutches are present, but the first following a rest is left out of account in rating the time between clutches.

- Female twins were produced at the close of this period. 
TABLE 5

Individual clutches of $\%$ A248 which yielded the two sexes

\begin{tabular}{|c|c|c|c|c|c|c|c|c|c|c|c|c|c|c|c|}
\hline 我 & 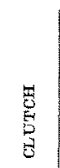 & 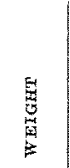 & 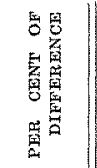 & 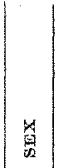 & $\begin{array}{l}\text { 漚 } \\
\text { 号 } \\
\text { 思 }\end{array}$ & 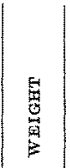 & 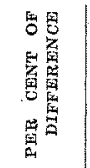 & is & 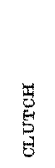 & 焉 & 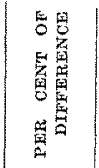 & w & $\begin{array}{l}\text { 䍖 } \\
\text { 鄫 }\end{array}$ & 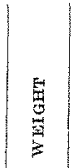 & 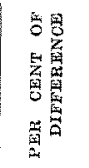 \\
\hline क) & G1 & 7.07 & & 8 & R1 & $7.63 \mid$ & & 우 & $\mathrm{H1}$ & 7.81 & & $0^{x}$ & M1 & 8.22 & \\
\hline q) & $\mathrm{G}_{2}$ & 8.28 & + & 우 & $\mathrm{R} 2$ & 7.79 & +2 & क & $\mathrm{H} 2$ & 9.17 & +17.4 & Q & M2 & 8.70 & +5. \\
\hline$\sigma^{\pi}$ & $\mathrm{K} 1$ & 6 & & q & $\mathrm{Z1}$ & 7.56 & & q & J1 & 7.18 & & 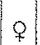 & S1 & 8.01 & \\
\hline १ & $\mathrm{K} 2$ & 8.29 & +22.4 & ? & $\mathrm{Z} 2$ & 8.48 & +12.2 & $? 0$ & $\mathrm{~J} 2$ & 8.51 & +18.5 & $0^{7}$ & $\mathrm{~S} 2$ & 8.70 & +8.6 \\
\hline 9. & L1 & 6.99 & & 8 & $\mathrm{~A} 1$ & 7.28 & & $a^{7}$ & K1 & 7.43 & & $a^{3}$ & W1 & 7.10 & \\
\hline$\pi$ & $\mathrm{L} 2$ & 8.36 & +19.6 & 이 & $\mathrm{A} 2$ & 8.47 & +16.3 & 우우 & $\mathrm{K} 2$ & 10.63 & +43.1 & Q & W2 & 8.47 & +19. \\
\hline
\end{tabular}

TABLE 6

Individual clutches of $\$ 60$ which yielded the two sexes

\begin{tabular}{|c|c|c|c|c|c|c|c|c|c|c|c|c|c|c|c|}
\hline 舅 & $\begin{array}{l}\text { 势 } \\
\text { 兽 }\end{array}$ & 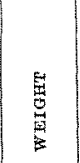 & 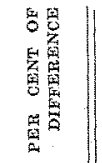 & 凅 & 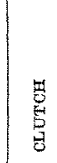 & 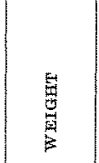 & 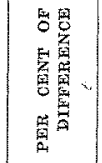 & 采 & $\begin{array}{l}\text { 葛 } \\
\text { 总 } \\
\text { 晋 }\end{array}$ & 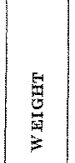 & 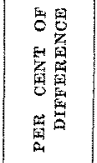 & 望 & $\begin{array}{l}\text { 菢 } \\
\text { 总 }\end{array}$ & 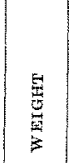 & 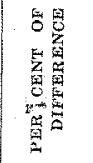 \\
\hline ㅇ & $\mathrm{Cl}$ & 7.50 & & $0^{7}$ & A1 & 7.915 & & 9 & II & 7.93 & & 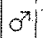 & U1 & 7.72 & \\
\hline 7 & $\mathrm{C} 2$ & 8.28 & +10.4 & $q$ & A2 & 8.150 & $\mid+2.9$ & -7 & $\mathrm{I} 2$ & 8.10 & +2.1 & 9 & $\mathrm{U} 2$ & 8.45 & +9.4 \\
\hline ㅇ & G1 & 8.48 & & 우 & E1 & 8.680 & & 7) & $J 1$ & 7.60 & & \% & $\mathrm{X} 1$ & 8.29 & \\
\hline $0^{7}$ & $\mathrm{G} 2$ & 9.00 & +6.1 & का & $\mathrm{E} 2$ & 8.650 & -0.3 & p & $J 2$ & 8.61 & +13.3 & il & $\mathrm{X} 2$ & 7.26 & -14.2 \\
\hline 우 & M1 & 8.09 & & $\sigma^{7}$ & F1 & 8.065 & & $0^{7}$ & M1 & 7.90 & & 3 & C1 & 7.69 & \\
\hline $0^{2}$ & M2 & 9.12 & +12.7 & $9 \%$ & $\mathrm{~F} 2$ & 10.080 & +24.9 & 8 & M2 & 8.38 & +6.1 & 91 & $\mathrm{C} 2$ & 7.79 & +1.3 \\
\hline $0^{x}$ & $\mathrm{R} 1$ & 8.290 & & $0^{7}$ & $\mathrm{G} 1$ & 7.700 & & $0^{7}$ & Q1 & 7.42 & & 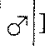 & E1 & 8.15 & \\
\hline 우 & $\mathrm{R} 2$ & 9.178 & +10.7 & 우 & G2 & 8.180 & +6.2 & 9 & Q2 & 7.48 & +0.8 & 01 & $\mathrm{E} 2$ & 9.10 & +11.6 \\
\hline$\sigma^{7}$ & S1 & 8.100 & & 우 & H1 & 7.08 & & i & $\mathrm{T} 1$ & 7.64 & & & & & \\
\hline 이 & $\mathrm{S} 2$ & 7.727 & -4.8 & $\sigma^{7}$ & $\mathrm{H} 2$ & 8.16 & {$[+15.2]$} & (7) & $\mathrm{T} 2$ & $|7.95|$ & +4.0 & & & & \\
\hline
\end{tabular}


TABLE 7

Clutches (pairs of eggs) of greatest size disparity laid by Streptopelia risoria

\begin{tabular}{|c|c|c|c|c|c|c|c|c|c|c|c|}
\hline \multirow[t]{8}{*}{61} & 욛 & 6.96 & & Hatched & & \multirow[t]{2}{*}{86} & 요1 & 7.290 & & \multicolumn{2}{|l|}{ Hatched ${ }^{1}$} \\
\hline & Q $\mathrm{H}_{2}$ & 8.55 & $+22.8^{2}$ & Hatched & & & वB2 & 8.870 & $+21.7^{2}$ & Hatched & \\
\hline & $\sigma^{7} \mathrm{Kl}$ & 6.77 & $\because$ & Hatched & & & or K1 & 7.150 & & Hatched & \\
\hline & \& K2 & 8.29 & +22.4 & Hatched & & & $\mathrm{o}^{7} \mathrm{~K} 2$ & $8: 740$ & +22.2 & Hatched & \\
\hline & १Q1 & 6.62 & & Hatched & & & 이 & 7.40 & & Hatched & \\
\hline & $\mathrm{Q} 2$ & 8.13 & +22.8 & Broken & & & 일 & 9.25 & +25.0 & Hatched & \\
\hline & $\mathrm{O}^{7} \mathrm{KI}$ & 7.43 & & Hatched & . & & q S1 & 7.300 & & Hatched & \\
\hline & १ $\mathrm{K} 2$ & 10.63 & +43.1 & Twins & & & $\mathrm{S} 2$ & 8.780 & +20.3 & Broken & \\
\hline 100 & $\mathrm{B1}$ & 8.270 & & 1.685 & & & $\sigma^{7 \top} \mathrm{T} 1$ & 6.980 & & Hatched & \\
\hline & B2 & 9.970 & +20.5 & 2.270 & $+34.7^{2}$ & & ๆ $\mathrm{T} 2$ & 8.410 & +20.5 & Hatched & \\
\hline $\mathrm{Y}$ & D1 & 7.550 & & 1.480 & & 141 & E1 & 7.66 & & Hatched ${ }^{1}$ & \\
\hline & D2 & 9.265 & +22.7 & 2.200 & +48.7 & & ○ $\mathrm{E2}$ & 9.22 & +20.3 & Hatched & \\
\hline & F1 & 8.410 & & 1.820 & & & $? \sigma^{7} \mathrm{~F} 1$ & $7: 28$ & & 10-12 da. & \\
\hline & $\mathrm{F} 2$ & 10.445 & +24.2 & 2.256 & +23.9 & & 우 $\mathrm{F} 2$ & 8.86 & +21.7 & Hatched & v \\
\hline 163 & A1 & 5.145 & & $0.943^{*}$ & & 122 & A1 & 7.010 & & 1.550 & \\
\hline & $\mathrm{A} 2$ & 6.550 & +27.3 & 1.170 & +24.1 & & $\mathrm{~A} 2$ & 8.730 & +24.5 & 2.052 & $+32.4^{2}$ \\
\hline & \% 1 & 7.47 & & Hatched & & & H1 & 7.420 & & 1.600 & \\
\hline & $9 \mathrm{D} 2$ & 9.04 & +21.0 & Hatched & & & $\mathrm{H} 2$ & 8.945 & +20.5 & 2.035 & +27.2 \\
\hline 118 & $\sigma^{7} \mathrm{X} 1$ & 7.005 & & Hatched & & & G1 & 7.400 & & 1.648 & \\
\hline & ○X2 & 8.635 & +23.2 & $\begin{array}{c}13-14 \text { da. } \\
\text { embr. }\end{array}$ & & & G2 & 9.045 & +22.2 & 2.132 & +29.4 \\
\hline
\end{tabular}

* Eggs thus marked are the first eggs in the life of the birds that produced them.

1 The purity of the female parent is questionable.

2 The figures of this column, in this table and in those which follow, represent the per cent of difference between the weights of the two eggs or of the two yolks. In all cases the smaller egg or yolk is taken as 100 per cent. 
TABLE 8

Clutches of eggs of greatest size disparity laid by hybrids of St. alba and St. risoria

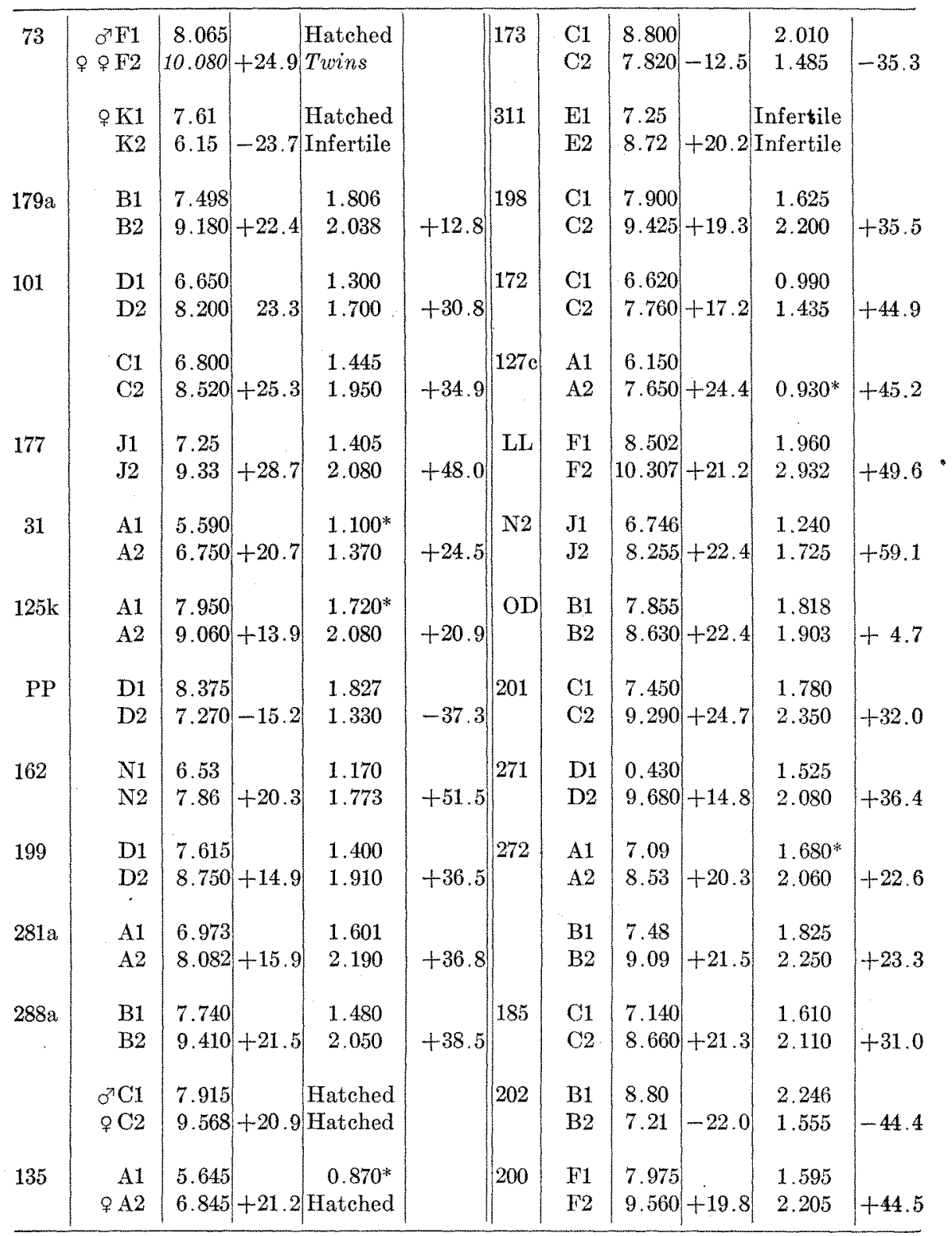


TABLE 8-Continued

\begin{tabular}{|c|c|c|c|c|c|c|c|c|c|c|c|}
\hline \multirow[t]{2}{*}{153} & B1 & 7.337 & & 1.672 & & & B1 & 8.325 & & 1.970 & \\
\hline & B2 & 9.015 & +22.8 & 1.818 & +8.7 & & B2 & 9.890 & +18.8 & 2.890 & +46.6 \\
\hline \multirow[t]{2}{*}{188} & E1 & 7.465 & & 1.825 & & & $\mathrm{H} 1$ & 7.515 & & 1.750 & \\
\hline & E2 & 9.050 & +21.2 & 2.055 & +12.6 & & $\mathrm{H} 2$ & 9.018 & +20.0 & 2.321 & +32.6 \\
\hline \multirow[t]{2}{*}{$153 a$} & $\mathrm{~A} 1$ & 6.850 & & $0.750^{*}$ & & $295 \mathrm{a}$ & A1 & 8.030 & & 1.678 & \\
\hline & $\mathrm{A} 2$ & 8.190 & +19.5 & 1.800 & +140.0 & & $\mathrm{~A} 2$ & 9.704 & +20.8 & 2.135 & +27.1 \\
\hline \multirow[t]{2}{*}{291} & F1 & 7.140 & & 1.550 & & 156 & D1 & 7.780 & & 1.580 & \\
\hline & $\mathrm{F} 2$ & 8.470 & +18.6 & 2.100 & +35.5 & & D2 & 9.660 & +24.1 & 1.975 & +25.0 \\
\hline \multirow[t]{4}{*}{$61 b$} & o $\mathrm{E} 1$ & 8.200 & & Hatched & & 159 & P1 & 6.70 & & Infertile & \\
\hline & १ E2 & 10.080 & +22.9 & Hatched & & & $\$ \mathrm{P} 2$ & 8.04 & +20.0 & Hatched & \\
\hline & 이 1 & 7.580 & & Hatched & & & १G1 & 7.54 & & Hatched & \\
\hline & $\sigma^{7} \mathrm{X} 2$ & 9.970 & +31.5 & Hatched & & & $9 \mathrm{C}_{2}$ & 9.36 & +24.1 & Hatched & \\
\hline \multirow[t]{9}{*}{105} & $?$ \% B1 & 7.010 & & Hatehed & & & $\mathrm{L} 1$ & 7.35 & & Broken & \\
\hline & $\sigma^{7} \mathrm{~B} 2$ & 8.590 & +22.5 & Hatched & & & ${ }^{7} \mathrm{~L} 2$ & 9.27 & +26.1 & Hatched & \\
\hline & $? 0^{x} \mathrm{C} 1$ & 7.242 & & 22 da. (1) & & & OM1 & 726 & & $\mathrm{Ha}$ & \\
\hline & $\mathrm{C} 2$ & 8.800 & +21.5 & $14 \mathrm{da}$. & & & $\mathrm{O}^{\mathrm{T}} \mathrm{M} 2$ & 8.97 & +23.5 & Hatched & \\
\hline & & & & & & & & & & & \\
\hline & M1 & 7.575 & & 1.625 & & 146 & $\sigma^{7} \mathrm{E} 1$ & 7.69 & & Hatched & \\
\hline & M2 & 9.340 & +23.5 & 2.039 & +25.5 & & १E2 & 9.57 & +24.4 & Hatched & \\
\hline & R1 & 7.630 & & 1.575 & & & B1 & 6.97 & & 1.520 & \\
\hline & $\mathrm{R} 2$ & 9.690 & +26.9 & 2.125 & +34.9 & & $\mathrm{~B} 2$ & 8.69 & +24.7 & 1.810 & +19.0 \\
\hline \multirow[t]{2}{*}{137} & $\mathrm{O}^{7} \mathrm{~B} 1$ & 7.140 & & Hatched & & 265 & \&1 & 8.36 & & Hatched & \\
\hline & $\mathrm{o}^{7} \mathrm{~B} 2$ & 8.700 & +21.8 & Hatched & & & ${ }^{7} \mathrm{Q} 2$ & 10.31 & +23.3 & Hatched & \\
\hline
\end{tabular}

* Eggs thus marked are the very first eggs in the life of the birds that produced them.

1 These eggs were the first after a long rest that followed a long peroid of reproductive overwork. It is also important to observe that they were fertilized by a generic hybrid (Zenaidura-Zenaida) male, and that these genera belong to a different subfamily from the female that produced these eggs. There is evidence that in this type of cross different sperms exercise opposite influence on the sex development.

It is of some interest to add that the male that developed from Q2 was killed when quite healthy; two testes were found, but, contrary to the rule for normal males, the left testis was larger than the right, i.e., the size relations of the glands were those of a female. (Riddle, Anat. Rec., vol. 14, 1918, pp. 283-334.) 
TABLE 9

Clutches of greatest size disparity laid by St. alba and by Turtur orientalis

\begin{tabular}{|c|c|c|c|c|c|c|c|c|c|c|c|}
\hline \multirow[t]{2}{*}{23} & QH1 & 7.210 & & Hatched & & 136 & K1 & 7.14 & & Infertile & \\
\hline & ?H2 & 8.860 & +22.9 & Hatched & & & $? \% \mathrm{~K} 2$ & 8.85 & +23.9 & Hatched & \\
\hline \multirow[t]{2}{*}{139} & L1 & 8.320 & & Lost & & & $\sigma^{7} \mathrm{~J} 1$ & 7.510 & & Hatched & \\
\hline & L2 & 10.042 & +20.7 & $\begin{array}{l}3 \text { da. } \\
\text { embr. }\end{array}$ & & & $? 0^{7} \mathrm{~J} 2$ & 9.030 & +20.2 & Hatched & \\
\hline \multirow[t]{2}{*}{155} & R1 & 9.10 & & 1.485 & & 97 & $J 1$ & 7.210 & & 1.276 & \\
\hline & $\mathrm{R} 2$ & 11.21 & +23.2 & 2,486 & +67.4 & & J2 & 8.920 & +23.7 & 1.503 & +17.8 \\
\hline
\end{tabular}

TABLE 12

Size disparity of eggs of common pigeons

\begin{tabular}{|c|c|c|c|c|c|c|c|c|c|c|c|}
\hline \multirow[t]{2}{*}{$291 a$} & $\mathrm{Bl}$ & 15.00 & & 3.080 & & 124 & Al & 17.365 & & 3.928 & \\
\hline & $\mathrm{B} 2$ & 15.38 & +2.5 & $1.760^{1}$ & $-75.0(?)$ & & A2 & 14,065 & -23.4 & 3.220 & -21 \\
\hline \multirow[t]{2}{*}{$3 \mathrm{Ft}}$. & B1 & 16.18 & & 3.190 & & 305 & A1 & 10 & & 0.995 & \\
\hline & B2 & 13.62 & -18.8 & 32.350 & -35 & & $\mathrm{~A} 2$ & 11. & +10.9 & 1.600 & +60.8 \\
\hline
\end{tabular}

1 It is quite probable that this figure was copied wrong when the weighing was made, and should be 2.760 . 
TABLE 10

Clutches of greatest size disparity laid by miscelbaneous hybrids (a few from pure species)

\begin{tabular}{|c|c|c|c|c|c|c|c|c|c|c|c|}
\hline \multirow[t]{2}{*}{$140 \mathrm{~b}$} & A1 & 6.618 & & $1.543 *$ & & 97 & $\sigma \mathrm{Kl}$ & 7.98 & & Hatched & \\
\hline & $\mathrm{A} 2$ & 8.357 & +26.2 & 1.940 & +25.7 & & K 2 & 9.84 & +23.3 & Hatched & \\
\hline \multirow[t]{2}{*}{$127 \mathrm{a}$} & K1 & 5.39 & & 1.095 & & 196 & $\sigma \mathrm{E} 1$ & 7.93 & & Hatched & \\
\hline & $\mathrm{K} 2$ & 6.72 & +24.7 & 1.160 & +5.9 & & 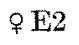 & 10.03 & +26.5 & Hatched & \\
\hline \multirow[t]{2}{*}{286} & $\mathrm{~A} 1$ & 6.34 & & $1.170^{*}$ & & 279 & A1 & 5.41 & & $1.080^{*}$ & \\
\hline & $\mathrm{A} 2$ & 8.35 & +31.7 & 1.850 & +58.1 & & $\mathrm{~A} 2$ & 6.73 & +24.4 & 1.540 & +42.6 \\
\hline \multirow[t]{3}{*}{117} & १D1 & 7.28 & & Hatched & & 286 & A1 & 6.34 & & 1.170 & \\
\hline & $\mathrm{D} 2$ & 10.31 & +41.6 & $2 \mathrm{da}$ & & & A? & 835 & +317 & & 1581 \\
\hline & & & & & & & A 2 & & +31.7 & 1.850 & +58.1 \\
\hline \multirow[t]{8}{*}{281} & $\mathrm{~B} 1$ & & & 0.840 & & 174 & I1 & 8.34 & & 1.710 & \\
\hline & $\mathrm{B} 2$ & & & 0.450 & -86.7 & & $\mathrm{I} 2$ & 5.28 & -57.9 & 1.738 & $+1.6^{1}$ \\
\hline & G1 & & & 0.690 & & 281 & J1 & 5.10 & & 1.075 &. \\
\hline & $\mathrm{G}_{2}$ & & & 0.450 & -53.3 & & $\mathrm{~J} 2$ & 5.23 & +2.5 & 1.480 & +37.7 \\
\hline & LI & $3.480^{2}$ & & 0.550 & & 273 & ९A1 & 5.94 & & Hatched & \\
\hline & L2 & 4.780 & +37.3 & 0.965 & +75.5 & & $\mathrm{~A} 2$ & 7.25 & +22.0 & $\begin{array}{c}2-3 \mathrm{da} . \\
\text { devel. }\end{array}$ & \\
\hline & $\mathrm{N} 1$ & $4.20^{\circ}$ & & 0.785 & & 5 & P1 & 6.700 & & 1.205 & \\
\hline & $\mathrm{N} 2$ & 1.96 & $\mid-114.3$ & 0.475 & -65.3 & & P2 & 6.920 & +3.3 & 1.783 & +47.9 \\
\hline \multirow[t]{2}{*}{181} & C1 & 3.985 & & 0.628 & & & E1 & 6.800 & & 1.420 & \\
\hline & $\mathrm{C} 2$ & 3.380 & -17.9 & 0.448 & -40.2 & & $\mathrm{E} 2$ & 5.650 & -20.3 & 1.043 & -36.1 \\
\hline \multirow[t]{2}{*}{54} & D1 & 9.165 & & 1.269 & & $114 \mathrm{a}$ & $\mathrm{L} 1$ & 7.940 & & 1.530 & \\
\hline & $\mathrm{D} 2$ & 10.120 & +10.4 & 1.713 & +35.0 & & $\mathrm{~L} 2$ & 9.690 & +22.0 & 1.640 & +7.2 \\
\hline
\end{tabular}

* Eggs thus marked are the very first eggs in the life of the birds that produced them.

1 This second yolk absorbed water from the albumen during fifty-two hours, the first yolk for only five hours; if this correction were made the second yolk would be shown to be smaller than the first.

${ }^{2}$ Many eggs with imperfect shells or without shells in this series. 
TABLE 11

Clutches of greatest size disparity laid by hybrids of St. alba and $T$. orientalis

\begin{tabular}{|c|c|c|c|c|c|c|c|c|c|c|c|}
\hline \multirow[t]{2}{*}{3} & E1 & 9.610 & & 2.244 & & 119 & B1 & 10.345 & & 2.840 & \\
\hline & $\mathrm{E} 2$ & 8.100 & $\mid-18.6$ & $3 \mid 1.485$ & -51.1 & & B2 & 8.005 & -29.2 & 1.620 & -75.3 \\
\hline \multirow[t]{2}{*}{98} & L1 & 8.600 & & $1.050^{\mathrm{T}}$ & & 100 & L1 & 10.050 & & 2.155 & \\
\hline & $\mathrm{L} 2$ & 6.970 & -23.4 & 1.560 & $+48.6(?)$ & & $\mathrm{L} 2$ & 8.360 & -20.2 & 1.870 & -15.2 \\
\hline \multirow[t]{4}{*}{49} & H1 & 9.535 & & 1.992 & & 100 & $\mathrm{~J} 1$ & 8.575 & & 1.430 & \\
\hline & $\mathrm{H} 2$ & 8.270 & -15.3 & 1.370 & -45.4 & & $\mathrm{~J} 2$ & 10.200 & +18.9 & 2.220 & +55.2 \\
\hline & E1 & 8.620 & & 1.534 & & & B1 & 9.310 & & 2.080 & \\
\hline & $\mathrm{E} 2$ & 9.800 & +13.7 & 2.220 & +44.7 & & $\mathrm{~B} 2$ & 11.500 & +23.5 & 3.020 & +45.2 \\
\hline \multirow[t]{2}{*}{103} & H1 & 8.915 & & 2.057 & & 89 & D1 & 7.27 & & 1.190 & \\
\hline & $\mathrm{H} 2$ & 6.730 & -32.4 & 0.975 & -110.97 & & D2 & 8.27 & +13.7 & 1.650 & +38.6 \\
\hline \multirow[t]{2}{*}{258} & G1 & 7.730 & & 1.450 & & & E1 & 8.76 & & 1.830 & \\
\hline & $\mathrm{G} 2$ & 9.590 & +24.0 & 2.440 & +68.3 & & E2 & 6.66 & $-31.5 \mid$ & 1.100 & -66.3 \\
\hline \multirow[t]{2}{*}{33} & $\mathrm{~T} 1$ & 7.260 & & 1.615 & & 65 & $\mathrm{~A} 1$ & 7.245 & & 1.498 & \\
\hline & $\mathrm{T} 2$ & 9.120 & +25.5 & 2.110 & +30.6 & & $\mathrm{~A} 2$ & 8.650 & +19.4 & 2.033 & +35.7 \\
\hline \multirow[t]{2}{*}{49} & L1 & 9.700 & & 2.088 & & & D1 & 7.505 & & 1.250 & \\
\hline & $\mathrm{L} 2$ & 7.360 & -31.8 & 1.480 & -41.1 & & $\mathrm{D} 2$ & 8.840 & +17.8 & 1.960 & +56.8 \\
\hline \multirow[t]{4}{*}{106} & G1 & 8.75 & & 1.510 & & & I1 & 8.870 & & 2.070 & \\
\hline & $\mathrm{G} 2$ & 9.94 & +13.6 & 2.162 & +43.2 & & $\mathrm{I} 2$ & 7.210 & -23.1 & 1.230 & -68.3 \\
\hline & $\mathrm{C} 1$ & 8.615 & & 1.466 & & & $\mathrm{~K} 1$ & 7.670 & & 1.380 & \\
\hline & $\mathrm{C} 2$ & 9.470 & +9.9 & 2.080 & +41.9 & & K2 & 9.250 & +20.6 & 2.001 & +45.0 \\
\hline \multirow[t]{2}{*}{115} & D1 & 8.370 & & 1.905 & & & F1 & 7.585 & & 1.355 & . \\
\hline & D2 & 6.017 & -39.1 & 0.915 & -108.2 & & $\mathrm{~F} 2$ & 9.035 & +19.1 & 1.906 & +40.7 \\
\hline \multirow[t]{4}{*}{30} & B1 & 8.455 & & 1.602 & & $56 a$ & $\mathrm{~J} 1$ & 8.670 & & 1.890 & \\
\hline & B2 & 9.800 & +15.9 & 2.800 & +37.3 & & $\mathrm{~J} 2$ & 6.505 & -33.2 & 1.220 & -54.9 \\
\hline & II & 7.755 & & 1.345 & & 29 & G1 & 9.520 & & 2.100 & \\
\hline & $\mathrm{I} 2$ & 9.605 & +23.8 & 2.115 & +57.2 & & $\mathrm{G} 2$ & 8.070 & -17.9 & 1.520 & -38.2 \\
\hline \multirow[t]{2}{*}{16} & $\mathrm{C} 1$ & 10.030 & & 2.530 & & & W1 & 8.100 & & 1.483 & \\
\hline & $\mathrm{C} 2$ & 8.600 & -16.6 & 1.810 & -39.8 & & W2 & 9.340 & +15.3 & 2.015 & +35.9 \\
\hline
\end{tabular}

${ }^{1}$ It is probable that this weight was 2.050 instead of 1.050 as recorded. The usual 'underscoring' of yolks of abnormal size for the bird or species was here omitted at the time of weighing. 
TAPLE 11-Continued

\begin{tabular}{|c|c|c|c|c|c|c|c|c|c|c|c|}
\hline \multirow{2}{*}{\multicolumn{2}{|c|}{$14 \mid \mathrm{El}$}} & 8.120 & & 1.295 & & 110 & $\mathrm{H} 1$ & 8.360 & & 1.525 & \\
\hline & & 8.350 & +2.8 & 1.845 & +42.5 & & $\mathrm{H} 2$ & 9.255 & +10.7 & 2.315 & +51.8 \\
\hline \multirow[t]{6}{*}{112} & $\mathrm{Cl}$ & 6.970 & & 1.150 & & & $\mathrm{~F} 1$ & 9.320 & & 1.925 & \\
\hline & $\mathrm{C} 2$ & 8.870 & +27.2 & 1.970 & +71.3 & & $\mathrm{~F} 2$ & 6.990 & -33.3 & 1.630 & -18.1 \\
\hline & L1 & 8.367 & & 2.120 & & 206 & @Z1 & 6.04 & & Incubated & \\
\hline & L2 & 6.795 & -23.1 & 1.700 & -24.7 & & $\sigma^{7} Z 2$ & 7.31 & +21.0 & Incubated & \\
\hline & B1 & 8.062 & & 1.940 & & 264 & A1 & 9.110 & & 1.520 & \\
\hline & B2 & 6.760 & -19.2 & 1.325 & -46.4 & & $A 2$ & 9.850 & +8.1 & 2.085 & +37.2 \\
\hline \multirow[t]{6}{*}{152} & A1 & 11.220 & & 3.035 & & 280 & G1 & 6.73 & & 1.290 & \\
\hline & A2 & 8.150 & -37.6 & 1.610 & -88.5 & & G2 & 5.78 & -16.4 & 0.850 & -51.8 \\
\hline & $\mathrm{C} 1$ & 8.340 & & 1.855 & & & $\mathrm{H} 1$ & 7.34 & & 1.150 & \\
\hline & $\mathrm{C} 2$ & 7.050 & -18.3 & 1.147 & -61.7 & & $\mathrm{H} 2$ & 5.76 & -27.4 & 0.930 & $-{ }_{t}^{*} 23.7$ \\
\hline & $\mathrm{H} 1$ & 8.180 & & 1.925 & . & & $\mathrm{K} 1$ & 5.57 & & 0.774 & \\
\hline & $\mathrm{H} 2$ & 7.095 & -15.3 & 1.240 & -55.2 & & $\mathrm{~K} 2$ & 6.57 & +17.9 & 1.268 & +63.8 \\
\hline & E1 & 8.950 & & 2.130 & & & D1 & 5.27 & & 0.645 & \\
\hline & $\mathrm{E} 2$ & 5.030 & -77.9 & 0.495 & -330.3 & & $\mathrm{D} 2$ & 6.82 & +29.3 & 1.320 & +104.6 \\
\hline & $\mathrm{F} 1$ & 7.270 & & 1.400 & & 285 & L1 & 9.830 & & 2.335 & \\
\hline & F2 & 9.180 & +26.2 & 2.280 & +62.8 & & $\mathrm{~L} 2$ & 8.600 & -14.3 & 1.630 & -43.3 \\
\hline & $\mathrm{H} 1$ & 7.940 & & 1.870 & & & $\mathrm{H} 1$ & 7.440 & & 1.235 & \\
\hline & $\mathrm{H} 2$ & 7.240 & -9.6 & 1.370 & -36.5 & & $\mathrm{H} 2$ & 9.180 & +23.4 & 2.160 & +74.9 \\
\hline & I1 & 7.990 & & 1.820 & & & D1 & 10.098 & & 2.502 & \\
\hline & $\mathrm{I} 2$ & 10.010 & +25.3 & 2.610 & +43.4 & & $\mathrm{D}^{2}$ & 8.677 & $|-16.3|$ & 1.835 & -36.3 \\
\hline & F1 & 9.410 & & 2.025 & & 18 & $\mathrm{~A} 1$ & 8.620 & & 1.625 & \\
\hline & $\mathrm{F} 2$ & 7.500 & -25.4 & 1.430 & -41.6 & & $\mathrm{~A} 2$ & 6.300 & -36.8 & 0.620 & -162.1 \\
\hline & G1 & 7.625 & & 1.267 & & & $\mathrm{~B} 1$ & 9.075 & & 1.840 & \\
\hline & G2 & 9.155 & +20.1 & 2.315 & +82.7 & & $\mathrm{~B} 2$ & 7.340 & -23.6 & 1.580 & -16.5 \\
\hline & K1 & 9.750 & & 1.873 & & 104 & G1 & 9.560 & & 1.968 & \\
\hline & $\mathrm{K} 2$ & 7.130 & -36.7 & 0.910 & -105.8 & & G2 & 7.817 & -22.3 & 1.665 & -18.2 \\
\hline & $\mathrm{Y} 1$ & 9.320 & & 2.213 & & 158 & $\mathrm{C} 1$ & 9.590 & & 1.920 & \\
\hline & $\mathrm{Y} 2$ & 7.440 & -25.3 & 31.443 & -53.4 & & $\mathrm{C} 2$ & 7.680 & -24.9 & 1.350 & -42.2 \\
\hline \multirow[t]{2}{*}{6} & $\mathrm{Y} 1$ & 6.640 & & 1.573 & & 18 & C1 & 8.680 & & 2.080 & \\
\hline & Y2 & 8.200 & +23.5 & 5.760 & +11.9 & & $\mathrm{C} 2$ & 7.550 & -14.9 & 1.472 & -43.3 \\
\hline \multirow[t]{2}{*}{49} & B1 & 8.290 & & 1.770 & & 46 & II & 6.940 & & 1.205 & \\
\hline & B2 & 7.440 & $\mid-11.4$ & 1.310 & -35.1 & & $\mathrm{I} 2$ & 5.570 & -24.6 & 0.782 & -54.1 \\
\hline
\end{tabular}




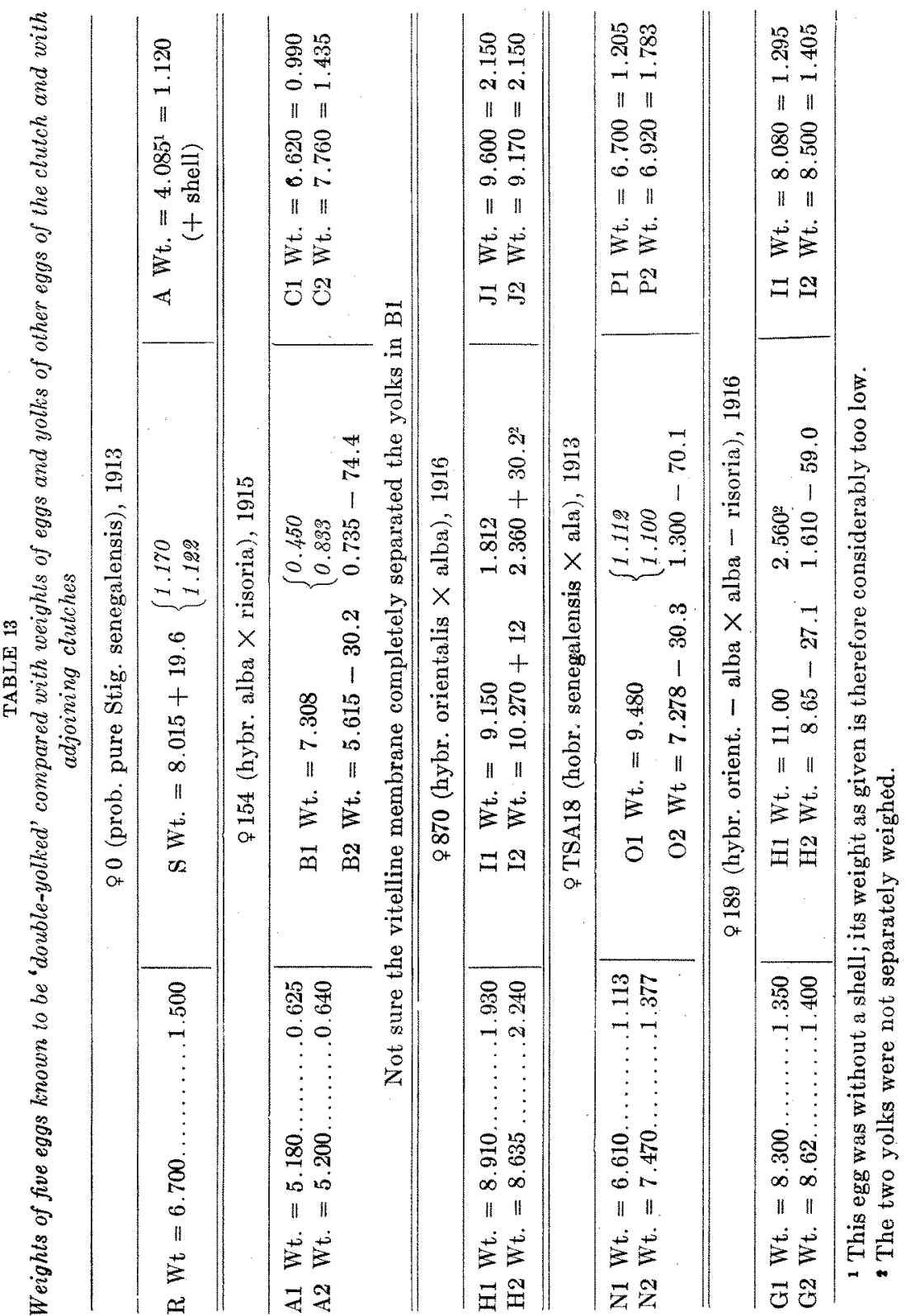

